\title{
ANALISIS PENERAPAN AKUNTANSI KEUANGAN PADA MASJID PARIPURNA DI PEKANBARU
}

\author{
Zulhelmy Mohd. Hatta \\ Universitas Islam Riau \\ zulhelmy@eco.uir.ac.id
}

\begin{abstract}
This article is aims to facilitate and broaden insight into the application of Plenary Mosque accounting based on PSAK 45 or ISAK 35, the research method is a survey (population is the entire Plenary Mosque of Marpoyan Damai District of Pekanbaru), as many as seven Plenary Mosque included in the SK Mayor of Pekanbaru. This research is based on field studies to obtain financial information as well as the management's response to interviews conducted by the researcher. The result of this research is that the Plenary Mosque management has not made a general journal, general ledger, balance sheet or activity report and others as the mosque accounting is arranged.So that the application of accounting for the Plenary Mosque is getting better, the Goverment as a facilitator can conduct socialization and training to each of its management (providing assistance). Although the application of accounting has not been able to applied to the fullest, the management can begin to improve financial information by implementing activity reports in accordance with the Mosque's accounting format.
\end{abstract}

Keywords:Mosque accounting, Plenary Mosque, PSAK 45, ISAK 35.

\begin{abstract}
ABSTRAK
Artikel ini bertujuan untuk memudahkan serta memperluas wawasan bagaimana penerapan akuntansi Masjid Paripurna berdasarkan PSAK 45 atau ISAK 35, metode Penelitian adalah Survei (populasinya seluruh Masjid Paripurna Kecamatan Marpoyan Damai Kota Pekanbaru), sebanyak tujuh Masjid Paripurna yang termasuk dalam SK Walikota Pekanbaru. Penelitian ini berbasis studi lapangan untuk memperoleh informasi keuangan sekaligus respon pengurus terhadap wawancara yang dilakukan oleh Peneliti. Hasil dari penelitian ini adalah Pengurus Masjid Paripurna belum membuat jurnal umum, buku besar, neraca saldo ataupun laporan aktivitas dan laiinya sebagai mana akuntansi masjid yang sudah diatur. Bentuk pertanggung jawaban Masjid Paripurna masih menggunakan pencatatan tunggal, atau lebih tepatnya akuntansi dana (menunjukkan sumber dana, dan penggunaannya disertai saldo setiap bulannya). Agar penerapan akuntansi Masjid Paripurna semakin baik, Pemerintah sebagai fasilitator dapat melakukan sosialisasi serta pelatihan kepada setiap Pengurusnya (melakukan pendampingan). Meskipun penerapan akuntansi belum bisa diterapkan secara maksimal, namun Pengurus dapat mulai memperbaiki informasi keuangan dengan menerapkan laporan aktivitas sesuai dengan format akuntansi Masjid.
\end{abstract}

Kata kunci: Akuntansi Masjid, Masjid Paripurna, PSAK 45, ISAK 35. 


\section{PENDAHULUAN}

Kota Pekanbaru mayoritas memiliki penduduk yang beragama Islam. Hal ini ditandai dengan banyaknya masjid yang sering kita temui, terutama di tempat publik. Banyaknya masyarakat muslim tentu memerlukan manajemen masjid yang harus selalu ditingkatkan. Perihal ini selaras dengan hal yaitu, dalam rangka membangun Smart City dan mewujudkan Pekanbaru Kota Metropolitan yang Madani, maka Pemerintah Kota Pekanbaru memiliki Program Masjid Paripurna. Salah satunya didukung dengan masyarakat Kota Pekanbaru yang mayoritas beragama Islam.

Masjid Paripurna sebagai program strategis pemerintah dan implementasi tugas pemerintah dalam melayani, membina dan memberdayakan masyarakat. Oleh karena Masjid paripurna menjadi masjid percontohan bagi masjid lainnya, yang memerankan masjid sebagai Habl Mina Allah dan Hablum Minan Nas. Sebuah artikel dari Sindonews (8 Mei 2019) memberitakan bahwasannya Pekanbaru Membangun Smart City Melalui Masjid Paripurna. Smart city merupakan cara mengimplementasikan Undang-Undang Dasar Negara Indonesia yaitu mencerdaskan kehidupan bangsa. Bangsa yang cerdas (smart nation) didukung oleh Provinsi, Kabupaten atau Kota yang cerdas. Untuk menjadikan sebuah kota yang cerdas maka masyarakatnya juga harus cerdas. Masyarakat cerdas adalah unsur utama dalam membangun kota.

Masjid Paripurna menjadi sebuah jembatan perantara bagi Pemerintah Kota untuk pusat pembinaan dan peningkatan iman dan taqwa serta pengembangan ilmu dan pengamalan akhlak dalam mewujudkan Kota Pekanbaru sebagai Kota Metropolitan yang Madani. Untuk mengimplementasikan program ini Pemerintah Kota Pekanbaru mengeluarkan PERDA Kota Pekanbaru No 2 Tahun 2016 Tentang Masjid Paripurna. Karena kota yang cerdas dibangun dengan enam pilar yaitu smart goverment, smart people, smart envinronment, smart economy, smart mobility, smart living. (Menurut Firdaus Walikota Pekanbaru). Perlu diketahui penetapan status Masjid menjadi Masjid Paripurna ditetapkan oleh keputusan Walikota. Dengan menimbang dan memperhatikan rekomendasi dari Tim Seleksi penetapan status Masjid Paripurna Kota Pekanbaru. Tim seleksi terdiri dari Pemerintah, Kementerian Agama, Majelis Ulama Indonesia, Akademisi dan Organisasi Keagamaan Islam di Kota Pekanbaru. Hal ini terdapat pada Bab II Status dan Kedudukan Pasal 2. (Perda No 2 Tahun 2016). 
Akuntansi tidak hanya digunakan pada organisasi bisnis, organisasi nirlaba juga menggunakannya. Realita yang terjadi di Indonesia, organisasi yang menggunakan dana masyarakat adalah organisasi sektor publik atau nama lainnya adalah organisasi nirlaba yang salah satunya meliputi organisasi peribadatan seperti Masjid, Gereja, Vihara dan Pura. (Bastian, Indra, 2011).

Berdasarkan pemaparan di atas maka, jelas bahwasanya masjid termasuk salah satu organisasi nirlaba. Yang mana menurut PSAK 45 dan ISAK 35 menjelaskan organisasi nirlaba memperoleh sumber daya dari sumbangan para anggota dan para penyumbang lain yang tidak mengharapkan imbalan apapun. Sebagai akibat dari karakteristik tersebut, dalam organisasi nirlaba timbul transaksi tertentu yang jarang atau bahkan tidak pernah terjadi dalam organisasi bisnis misalnya penerimaan sumbangan. (Hendrawan, Rony, 2011). Manajemen organisasi profit dan non profit akan selalu dihadapkan terhadap tindakan pengambilan keputusan. Bagus tidaknya suatu keputusan bergantung pada informasi yang diperoleh. Sumber informasi penting salah satunya adalah laporan keuangan yang hal ini dalam bidang keuangan. (Najmudin, 2011).

Menurut PERDA No 2 Tahun 2016 jelas dinyatakan pada pasal 13 Ayat (2) Penatalaksanaan keuangan yang berasal dari infak, sodaqah dan waqaf dari umat Islam serta sumber lainnya yang sah dan tidak mengikat dilaksanakan secara transparency, accountable serta dilaporkan secara teratur dan berkala kepada jamaah dan dalam rapat kerja badan pengelola. Ayat (3) Laporan keuangan dapat dipertanggungjawabkan serta diperiksa oleh Dewan Pengawas Badan Pengelola Masjid Paripurna.

Hal ini berarti menjadi sebuah tuntutan kepada seluruh pengurus Masjid Paripurna agar membuat laporan keuangan yang berpedoman pada PSAK 45 atau ISAK 35 agar laporan keuangan bersifat transparency dan accountable (dapat dipertanggungjawabkan). Sehinggapihak-pihak pengguna laporan keuangan, masyarakat serta pemerintah dapat mendapatkan informasi yang akurat. Tuntutan lain yang tidak kalah penting adalah karena transparansi mengenai alokasi sumbangan ataupun dana yang diperoleh. Sebab masjid termasuk organisasi nirlaba yang mengharuskan akses yang mudah didapatkan oleh publik.

Dalam pengetahuan, akuntansi dapat diartikan sebagai seperangkat pegetahuan yang mempelajari penyediaan jasa berupa informasi keuangan kuantitatif, unit-unit, organisasi dalam satu lingkungan negara tertentu dan cara penyampaiannya (pelaporan), informasi tersebut 
digunakan terhadap kepada pihak yang berkepentingan untuk dijadikan dasar dalam pengambilan keputusan ekonomi. (Suwardjono,2014).

Selama ini pengurus masjid paripurna menganggap informasi keuangan yang disampaikan setiap minggu kepada jamaah sudah termasuk laporan keuangan. Hal ini karena kurang memerhatikan pedoman yang sudah diatur PSAK 45 atau ISAK 35 serta kebijakan yang sudah dikeluarkan oleh pemerintah Kota Pekanbaru yaitu PERDA No 2 Tahun 2016 tentang Masjid Paripurna. Untuk pihak internal tujuan laporan keuangan adalah untuk mengetahui situasi keuangan yang ada dalam organisasi tersebut, sedangkan untuk pihak eksternal bertujuan untuk mengetahui apakah dana yang ada telah dipergunakan dengan baik dan terlampir dalam laporan keuangan organisasi tersebut.

Penelitian sebelumnya yang dilakukan Wiwin Kurniasari (2011), dengan judul Transparansi Pengelolaan Masjid dengan Pelaporan Keuangan Berdasarkan PSAK 45 hasilnya adalah laporan yang dibuat masih terbatas pada laporan arus kas saja, belum berdasarkan pada PSAK 45. Penelitian oleh (Chenly Ribka S.Pontoh,2013) dengan judul Penerapan Laporan Keuangan Organisasi Nirlaba Berdasarkan PSAK No 45 Pada Gereja Bukit Zaitun Luwuk Manado Sulawesi. Hasilnya adalah belum sesuai dengan PSAK 45. Penelitian selanjutnya, yang dilakukan oleh Fikal Putra (2018), dengan judul Analisis Penerapan Akuntansi Dan Pelaporan Keuangan Pada Masjid Paripurna Di Pekanbaru (Studi Kasus Pada Masjid Paripurna Al-Falah Darul Mutthaqin) hasil peneltian nya adalah bahwa penerapan pelaporan keuangan yang dilakukan pada Masjid Paripurna Al-Falah Darul Mutthaqin belum sesuai dengan PSAK NO 45.

Masjid merupakan rumah ibadah dari umat Islam. Yang mana laporan keuangannya mengacu kepada PSAK 45 atau ISAK 35. Maka ada tuntutan bagi Pengurus Masjid untuk melakukan perbaikan laporan keuangan yang berpedoman pada PSAK 45 atau ISAK 35. Sebagai pertanggungjawaban sumbangan atau dana yang telah diterima.

Survei awal dilakukan pada Masjid Paripurna Al Hikmah Tingkat Kelurahan Maharatu. Diperoleh data pencatatan keuangannya dilakukan setiap ada pemasukan dan pengeluaran dengan format yang sudah dibuat pengurus masjid paripurna Al Hikmah. Pencatatan berisi informasi mengenai pemasukan (kas masjid, kas anak yatim, kas TPA) dan pengeluaran (seperti biaya pembangunan, wirid rutin, keperluan masjid dan lain-lain).

Pencatatan diinformasikan juga pada mading pengumuman. Tidak selalu membuat 
pembukuan, tidak membuat jurnal setiap ada pemasukan dan pengeluaran serta laporan keuangan yang lainnya. Kedua, pada Masjid Paripurna Lillah Tingkat Kelurahan Sidomulyo Timur dari data yang diperoleh diketahui pengurus melakukan pencatatan sesuai dari sumber yang diperoleh seperti infak jum'at, infak harian, infak anak yatim dan infak untuk Yayasan Lillah.

Sementara pengeluaran keperluan masjid seperti wirid rutin, pembayaran listik, sampah, gaji imam rawatib, pembuatan laporan, photo copy dan lainnya. Pencatatan keuangan masih dilakukan secara manual, untuk laporan lainnya sudah dilakukan sesuai aturan PERDA NO 2 Tahun 2016. Tidak membuat jurnal setiap ada pemasukan atau pengeluaran, serta laporan keuangan yang lainnya. Keuangan ditulis juga pada mading pengumuman.

Ketiga, survei pada Masjid Paripurna Al Mujahadah Tingkat Kelurahan Wonorejo membuat pencatatan dengan format yang sudah disiapkan, pembukuan, serta ditulis pada mading informasi masjid. Dari pembukuan diketahui beberapa program yaitu pemasukan dan pengeluaran untuk masjid, pembangunan, anak yatim, pendidikan serta program umroh. Tidak membuat jurnal setiap ada pemasukan atau pengeluaran, begitu juga dengan laporan keuangan lainnya. Infomasi keuangan juga terdapat pada mading pengumuman.

Keempat, Masjid Paripurna Al Kautsar Tingkat Kecamatan Marpoyan Damai pencatatan masih secara manual setiap minggu. Tidak selalu membuat pembukuan. Informasi keuangan berupa transaksi-transaksi yang berkaitan dengan kas masuk, infak, sumbangan serta pengeluaran masjid. Namun tidak membuat jurnal yang semestinya disetiap transaksi. Tidak seluruhnya mendokumentasikan laporan rutin masjid.

Kelima, Masjid Paripurna Al Manar Tingkat Kelurahan Tangkerang Barat membuat pencatatan berupa kas masjid, anak yatim serta fakir miskin. Informasi keuangan ditulis juga pada mading masjid. Tidak membuat jurnal setiap transaksinya dan tidak pula membuat laporan keuangan lainnya.

Keenam, Masjid Paripurna Al Ikhwan Tingkat Kelurahan Perhentian Marpoyan, dari data yang didapat pencatatan masih dilakukan secara manual berisi informasi pemasukan (infak jum'at, infak wirid, sumbangan masyarakat dan lainnya), sementara pengeluaran berupa biaya wirid, keperluan dan perawatan masjid, listrik dan lainnya. Tidak membuat jurnal setiap ada pemasukan atau pengeluaran. Masih jarang membuat pembukuan.

Ketujuh, sama halnya dengan masjid sebelumnya, Masjid Ijtihadul Muslimin Tingkat 
Kelurahan Tangkerang Tengah masih melakukan pencatatan dan pembuuan secara manual. Informasinya berupa kas masjid, MDA, anak yatim, serta pengeluaran yang lainnya. Tidak membuat jurnal setiap ada pemasukan atau pengeluaran begitu juga dengan laporan keuangan lainnya.Pentingnya membuat jurnal setelah suatu transaksi karena pencatatan akuntansi yang pertama dilakukan adalah jurnal.

Dibanding dengan catatan akuntansi yang lain, pencatatan dalam jurnal ini biasanya lebih lengkap dan lebih terinci serta menurut urutan tanggal kejadian. Transaksi dan jurnal merupakan catatan akuntansi permanen yang pertama, digunakan untuk mencatat transaksi keuangan perusahaan ataupun sebuah organisasi. Catatan yang dilakukan di dalamnya lengkap dengan penjelasan tanggal dan informasi lain agar catatan tersebut mudah untuk diproses ke dokumen sumbernya. (Pulungan,Andrey Hasiholan,dkk,2013).

Terdapat perbedaan yang cukup terlihat dari penelitian ini dengan penelitian- penelitian sebelumnya, diantaranya adalah (1) objek penelitian, (2) lokasi penelitian, (3) ruang lingkup pada penelitian ini lebih luas yakni seluruh Masjid Paripurna yang berada di Kecamatan Marpoyan Damai Kota Pekanbaru. Ada perbedaan yang cukup signifikan, antara data yang diperoleh dari para pengurus Masjid Paripurna, dengan prinsip akuntansi berterima umum berdasarkan pada PSAK 45 atau ISAK 35, maka perlu dilakukan penelitian terhadap penerapan akuntansi mesjid pada mesjid paripurna di Pekanbaru.

\section{TEORI DAN PENGEMBANGAN HIPOTESIS}

Secara umum organisasi terbagi menjadi dua, yakni organisasi nirlaba dan organisasi bisnis. Organisasi nirlaba atau sering disebut organisasi non profit yang tujuan utama nya adalah bukan untuk mencari keuntungan. Sebaliknya Organisasi bisnis yang tujuan utamanya adalah mencari keuntungan yang sebesar-besarnya.

Di Indonesia, organisasi yang menggunakan dana masyarakat adalah organisasi sektor publik atau nama lainnya adalah organisasi nirlaba yang salah satunya meliputi organisasi peribadatan seperti organisasi dalam sebuah tempat peribadatan yaitu Masjid, Mushala, Gereja, Kuil, Klenteng, Wihara, maupun Pura. Maka dapat dikatakan, organisasi keagamaan dijalankan oleh sebuah lembaga atau organisasi yang muncul atas kesadaran akan berjalannya visi dan misi agama tertentu (Bastian, Indra, 2011).

Sedangkan organisasi nirlaba merupakan suatu organisasi yang bertujuan utamanya untuk mendukung serta melayani kepentingan publik yang tidak berhubungan dengan 

perdagangan. Organisasi nirlaba meliputi organisasi keagamaan, sekolah, rumah sakit dan klinik publik, organisasi politik, organisasi masyarakat, organisasi sukarelawan, serikat buruh. Maka salah satu organisasi yang termasuk organisasi nirlaba yaitu Masjid. Masjid merupakan rumah ibadah umat muslim. Organisasi Masjid merupakan organisasi sektor publik yang menerima, mengelola keuangan dan sumber daya lain dari para jamaah.

Sumber dan pemanfaatan sumber daya antara keduanya pun berbeda juga. Jika pada organisasi Nirlaba sumber daya akan digunakan untuk menjalankan aktivitas organisasi. Sumber daya organisasi nirlaba diperoleh dari Sumbangan baik yang berasal dari anggota maupun para penyumbang lain (masyarakat) yang tidak mengaharapkan pamrih. Maka pada organisasi nirlaba terdapat salah satu transaksi yang berbeda dari organisasi bisnis yakni penerimaan sumbangan. (Hendrawan, Rony, 2011).

Berdasarkan pengertian tersebut, maka (Badu dan Hambali, 2014) dalam manajemen keuangan terdapat dua fungsi yaitu : Fungsi mendapatkan dana, dan fungsi menggunakan dana. Akuntansi organisasi nirlaba meliputi bentuk laporan keuangan dan nama-nama rekening berdasarkan pola PSAK 45. Unsur-unsur laporan keuangan berdasarkan PSAK adalah; (1) Laporan posisi keuangan; (2) Laporan aktivitas; (3) Laporan arus kas, dan(4) Catatan atas laporan keuangan (Bastian, Indra,2011).

\section{PSAK 45 (Pernyataan Standar Akuntansi Keuangan45)}

PSAK 45 adalah standar maupun patokan khusus yang di gunakan untuk organisasi nirlaba. Ciri-ciri organisasi nirlaba sangat berbeda dengan organisasi profit yang tujuannya adalah untuk memperoleh laba. Sumber dan pemanfaatan sumber daya antara keduanya pun berbeda juga. Jika pada organisasi Nirlaba sumber daya akan digunakan untuk menjalankan aktivitas organisasi.

Sumber daya organisasi nirlaba di peroleh dari sumbangan baik yang berasal dari anggota maupun para penyumbang lain (masyarakat) yang tidak menaharapkan pamrih. Maka pada organisasi nirlaba terdapat salah satu transaksi yang berbeda dari organisasi bisnis yakni penerimaan sumbangan. (Hendrawan, Rony, 2011).

Dalam ruang lingkup PSAK 45 tentang Pelaporan Keuangan Organisasi Nirlaba, dikatakan bahwa sebuah organisasi nirlaba harus memenuhi karakteristik sebagai berikut:

a) Sumber daya berasal dari para donatur yang tidak mengharapkan pembayaran 
kembali atau manfaat ekonomi yang sebanding dengan jumlah sumber daya yangdiberikan.

b) Menghasilkan barang dan atau jasa tanpa bertujuan memupuk laba, dan kalau suatu entitas menghasilkan laba, maka jumlahnya tidak pernah dibagikan kepada para pendiri atau pemilik entitas tersebut. Tidak ada kepemilikan seperti lazimnya pada organisasi nirlaba tidak dalam arti bahwa kepemilikan dalam organisasi nirlaba tidak dapat dijual, dialihkan, atau ditebus kembali, atau kepemilikan tersebut tidak mencerminkan proporsi pembagian sumber daya entitas pada saat likuidasi atau pembubaran entitas.

\section{Penyajian Laporan Keuangan Berdasarkan PSAK45}

Menurut PSAK 45 (IAI, 2015) manyatakan laporan keuangan organisasi nirlaba terdiri dari Laporan keuangan organisasi nirlaba menurut PSAK 45 meliputi: Laporan Posisi Keuangan Pada AkhirPeriode, laporan aktivitas, Laporan arus kas untuk satu periode laporan, dan catatan atas laporan keuangan.

Organisasi Peribadatan Pada umumnya manajemen keuangan didefinisikan sebagai pengorganisasi kekayaan yang ada pada suatu organisasi untuk mencapai tujuan yang ingin dicapai organisasi tersebut. Dengan kata lain, definisi yang lain mengatakan manajemen keuangan adalah kegiatan untuk memperoleh dan menggunakan dana dengan tujuan meningkatkan atau memaksimalkan nilai organisasi.

Dalam konteks organisasi peribadatan, manajemen keuangan organisasi peribadatan adalah usaha yang dilakukan pengelola tempat peribadatan dalam menggunakan dana umat sesuai dengan ketentuan dalam ajaran agama dan kepentingan umat beragama, serta bagaimana memperoleh dana dari umat dari cara-cara yang dibenarkan oleh ajaran agama.

\section{ISAK 35 (Interpretasi Standar AkuntansiKeuangan)}

ISAK 35 memberikan pedoman penyajian laporan keuangan untuk entitas berorientasi nonlaba dan dapat diterapkan juga, organisasi nonlaba yang menggunakan SAK ETAP. ISAK 35 tidak membatasi penggunaan judul tertentu selama judul tersebut masih memiliki fungsi yang sesuai. Contoh dalam ISAK 35 ini tidak ditujukan untuk mengilustrasikan seluruh aspek dari SAK atau mencakup bentuk dari seluruh organisasi non laba, karena dapat berbeda dari kondisi setiap organisasi non laba tersebut. 
H: Penerapan Akuntansi Keuangan di Masjid Paripurna Kota Pekanbaru belum sesuai dengan Prinsip Akuntansi Berterima Umum (PABU)

\section{METODE PENELITIAN}

Metode penelitian yang digunakan dalam penelitian ini adalah metode deskriptif, yakni membandingkan antara praktik yang ada dengan teori, konsep dan Prinsip. Dalam hal ini praktik akuntansi di Mesjid Paripurna kota Pekanbaru dibandingkan dengan Prinsip Akuntansi Berterima Umum (PABU).

\section{Objek dan Lokasi Penelitian}

Objek penelitian ini adalah seluruh Masjid Paripurna yang berada di wilayah Kecamatan Marpoyan Damai Kota Pekanbaru, Provinsi Riau. Alasan yang mendasari Peneliti mengambil lokasi penelitian di Kecamatan Marpoyan Damai adalah karena para pengurus Masjid Paripurna di wilayah ini sudah menerapkan pencatatan maupun pembukuan, baik secara manual maupun dengan microsoft excel.

Selain itu juga terdapat satu Masjid Paripurna yakni Masjid Lillah (Masjid Paripurna tingkat Kelurahan Sidomulyo Timur) yang hampir secara keseluruhan sudah menerapkan semua PERDA No 2 Tahun 2016 yang dikeluarkan Pemerintah Kota Pekanbaru Riau. Alasan-alasan tersebut yang membuat peneliti tertarik untuk meneliti di Kecamatan Marpoyan Damai, Kota Pekanbaru, Riau.

\section{Populasi dan Sampel}

Seperti yang sudah di jelaskan di atas bahwasannya objek penelitian ini adalah seluruh Masjid Paripurna yang berada di wilayah Kecamatan Marpoyan Damai Kota Pekanbaru, Provinsi Riau. Berdasarkan informasi yang diperoleh dari Kantor Camat Marpoyan Damai ada tujuh Masjid Paripurna yang sudah ditetapkan oleh Pemerintah Kota Pekanbaru. Seluruh populasi dijadikan sampel penelitian atau disebut juga dengan metode Sensus. Berikut merupakan data Masjid Paripurna Kecamatan Marpoyan Damai: 
Tabel 1 Daftar nama-nama Masjid Paripurna di Kecamatan MarpoyanDamai

\begin{tabular}{|c|c|c|}
\hline No & Nama Masjid Paripurna & Lokasi Masjid Paripurna \\
\hline 1 & MASJID AL-KAUTSAR PARIPURNA KECAMATAN & $\begin{array}{c}\text { Jl.Neraca No.74, Kelurahan } \\
\text { Tangkerang Tengah, Kecamatan } \\
\text { Marpoyan Damai }\end{array}$ \\
\hline 2 & $\begin{array}{l}\text { MASJID LILLAH PARIPURNA KELURAHAN } \\
\text { SIDOMULYO TIMUR }\end{array}$ & $\begin{array}{c}\text { Jl.Adi Sucipto, Kelurahan } \\
\text { Sidomulyo Timur, Kecamatan } \\
\text { Marpoyan Damai } \\
\end{array}$ \\
\hline 3 & $\begin{array}{l}\text { MASJID AL MUJAHADAH PARIPURNA } \\
\text { KELURAHAN WONOREJO }\end{array}$ & $\begin{array}{l}\text { Jl.Taskurun, Kelurahan Wonorejo, } \\
\text { Kecamatan MarpoyanDamai }\end{array}$ \\
\hline 4 & $\begin{array}{l}\text { MASJID IJTIHADUL MUSLIMIN PARIPURNA } \\
\text { KELURAHAN TANGKERANG TENGAH }\end{array}$ & $\begin{array}{c}\text { Jl.Wonosari RW 09/RT 01, } \\
\text { Kelurahan Tangkerang Tengah, } \\
\text { Kecamatan Marpoyan Damai }\end{array}$ \\
\hline 5 & $\begin{array}{l}\text { MASJID AL IKHWAN PARIPURNA KELURAHAN } \\
\text { PERHENTIAN MARPOYAN }\end{array}$ & $\begin{array}{c}\text { Jl.Parkit X No.254, Kelurahan } \\
\text { Perhentian Marpoyan, Kecamatan } \\
\text { Marpoyan Damai }\end{array}$ \\
\hline 6 & $\begin{array}{l}\text { MASJID AL MANAR PARIPURNA KELURAHAN } \\
\text { TANGKERANG BARAT }\end{array}$ & $\begin{array}{c}\text { Jl.Tongkol No.21 RW 01 RT 04, } \\
\text { Kelurahan Tangkerang Barat, } \\
\text { Kecamatan Marpoyan Damai }\end{array}$ \\
\hline 7 & $\begin{array}{l}\text { MASJID AL HIKMAH PARIPURNA KELURAHAN } \\
\text { MAHARATU }\end{array}$ & $\begin{array}{c}\text { Jl.Pahlawan Kerja, Kelurahan } \\
\text { Maharatu, Kecamatan Marpoyan } \\
\text { Damai }\end{array}$ \\
\hline
\end{tabular}

Sumber :Kecamatan Marpoyan Damai Kota Pekanbaru, Riau

\section{Jenis dan SumberData}

Data merupakan informasi yang didapatkan dari suatu penelitian, media sosial, maupun hasil lapangan. Sehingga dapat digunakan untuk mengetahui fenomena yang terjadi dan selanjutnya solusi untuk memperbaikinya.

Jenis dan sumber data yang di kumpulkan Peneliti pada penelitian ini adalah data primer yang diperoleh dari rekaman, pengamatan,wawancara, atau bahan tertulis dari para pengurus Masjid Paripurna di Kecamatan Marpoyan Damai Kota Pekanbaru. Sedangkan data sekunder berupa laporan keuangan harian (mingguan), laporan keuangan bulanan baik penerimaan atau pun pengeluaran yang meliputi sumbangan, infak, sedekah dan lain-lain.

\section{Teknik PengumpulanData}

Pengumpulan data dilakukan dengan cara mengumpulkan laporan keuangan baik pencatatan maupun pembukuan seluruh Masjid Paripurna Kecamatan Marpoyan Damai Kota 
Pekanbaru. Teknik yang dilakukan yakni : Teknik Wawancara (Interview), yaitu teknik pengumpulan data yang dilakukan dan diperoleh dengan mengadakan sesi tanya jawab langsung dengan pihak-pihak yang berkepentingan dan terlibat langsung dengan masalah yang dibahas dalam penelitian ini. Data yang diperoleh langsung dari informan dan dapat berupa kalimat tertulis atau lisan, perilaku, fenomena, peristiwa-peristiwa, pengetahuan. Peneliti melakukan wawancara terhadap para pengurus masjid paripurna (Badan Pengelola Masjid) seperti Ketua, Bendahara, maupun Sekretaris.

1. Survei lapangan, dimana peneliti melakukan pengamatan langsung keobjek penelitian untuk mendapatkan data-data yang diperlukan.

2. Dokumentasi merupakan teknik pengumpulan data dengan cara melakukan pengambilan dokumen yang ada, seperti pencatatan dan pembukuan, serta mendokumentasikan seluruh Masjid Paripurna di Kecamatan Marpoyan Damai.

\section{Metode AnalisisData}

Metode analisis data yang digunakan untuk penelitian ini adalah metode deskriptif. Hal ini dilakukan guna untuk melihat antara data yang sudah diperoleh dengan teori-teori yang sudah ada. Kemudian hasil penelitian yang telah diperoleh akan dibandingkan dengan kriteria-kriteria yang digunakan. Agar dapat diperbaiki sesuai PSAK 45 dan ISAK 35 kemudian ditarik suatu kesimpulan. Adapun pedoman untuk penelitian ini, yaitu PSAK 45 atau ISAK 35 tentang pelaporan keuangan entitas berorientasi nonlaba.

1) Untuk menganalisis data, metode yang digunakan adalah sebagai berikut: Mengumpulkan data dan informasi dari Masjid Paripurna di Kecamatan Marpoyan Damai Kota Pekanbaru baik berupa informasi keuangan, laporan pertanggung jawaban, foto dokumentasi sertawawancara.

2) Menganalisis data dan informasi yang diperoleh terutama mengenai informasi keuangan Masjid berdsarkan pedoman PSAK 45 atau ISAK 35, agar dapat diperbaiki sesuai dengan standar akuntansi keuangan yang berlaku.

\section{HASIL PENELITIAN DAN PEMBAHASAN}

Informasi yang dipaparkan merupakan informasi yang diperoleh dari Responden baik berdasarkan pertanyaan wawancara terstruktur maupun wawancara yang sifatnya spontanitas. Yang dimaksud dengan Responden disini adalah beberapa pengurus Masjid Paripurna. Berdasarkan informasi yang diperoleh dari pengurus Masjid Paripurna serta pihak kecamatan 
baik wawancara maupun data (informasi mengenai keuangan) maka hasil penelitian ini adalah sebagai berikut:

Tabel 2 Masa Kepengurusan Masjid Paripurna

\begin{tabular}{ccc}
\hline Pertanyaan Umum & $<$ 1 Tahun & $>1$ Tahun \\
\hline 1. & 1 Orang & 9 Orang
\end{tabular}

\section{Sumber: Hasil Lapangan}

Diperoleh hasil lapangan berdasarkan wawancara mengenai pertanyaan umum yang dilakukan maka tabel 2 menunjukkan masa kepengurusan Pengurus Masjid Paripurna yakni satu Orang kurang dari satu tahun dan sembilan Orang lebih dari satu tahun.

Tabel 3 Pembukuan dan Pencatatan

\begin{tabular}{cccc}
\hline Pertanyaan & Ya & Tidak & Lainnya \\
\hline 1. & 10 Orang & - & - \\
\hline 2. & 10 Orang & - & - \\
\hline 3. & - & - & 10 Orang \\
\hline 4. & 5 Masjid & - & 2 Masjid \\
\hline 5. & - & 10 Orang & - \\
\hline 6. & 10 Orang & - & - \\
\hline 7. & 10 Orang & - & - \\
\hline
\end{tabular}

Sumber: Hasil Lapangan

Kemudian tabel 3 adalah menunjukkan jawaban wawancara dari para Pengurus Masjid Paripurna yakni:

1) Pertanyaan pertama mengenai kas, sepuluh orang Pengurus Masjid Paripurna mengenal istilah kas.

2) Pertanyaan kedua mengenai penerimaan dan pengeluaran hasilnya adalah sepuluh orang Pengurus Masjid Paripurna mencatat penerimaan dan pengeluaran.

3) Pertanyaan ketiga mengenai berapa kali melakukan pembukuan hasilnya adalah sepuluh orang Pengurus Masjid Paripurna melakukan pembukuan sekitar kurang dari dua belas bulan sekali atau (1 tahun sekali).

4) Pertanyaan keempat mengenai sumber dana yang diperoleh lima Masjid Paripurna sumber dananya berasal dari jamaah dan donatur, sumbangan, masyarakat sekitar dan infak jum'at serta infak harian. Sementara dua Masjid Paripurna memperoleh 
dana dari jamaah dan donatur, sumbangan, masyarakat sekitar dan infak jum'at serta infak harian dan Pemerintah Kota Pekanbaru (dengan membuat dana talangan terlebih dahulu serta laporan pertanggung jawaban yang diserahkan kantor kecamatan Marpoyan Damai).

5) Pertanyaan kelima mengenai apakah pengurus menerima dana dari Pemerintah Kota Pekanbaru hasilnya adalah sepuluh orang pengurus tidak menerimanya karena hanya para petugas masjid yang termasuk SK yang mendapat gaji dengan cara transfer pada rekening masing-masing petugas Masjid Paripurna.

6) Pertanyaan keenam mengenai apakah Pengurus Masjid Paripurna selalu mencatat transaksi baik dari jamaah, donatur dan lainnya hasilnya adalah sepuluh orang pengurus selalu mencatat transaksi yang terjadi.

7) Pertanyaan ketujuh mengenai apakah Masjid Paripurna membuat laporan hasilnya adalah tujuh Masjid Paripurna membuat laporan pertanggung jawaban serta laporan yang disampaikan kepada jamaah melalui pengumuman dan ditulis di papan informasi masing-masing Masjid Paripurna.

Hasil penelitian lainnya yang diperoleh adalah Masjid Paripurna di Kecamatan Marpoyan Damai Kota Pekanbaru hanya membuat informasi keuangan dengan pencatatan tunggal (single entry) dan ini juga diberlakukan untuk pembukuan. Pengurus Masjid Paripurna tidak membuat jurnal umum serta laporan keuangan sebagai manamestinya. Pembahasan pada penelitian ini merupakan kekurangan penerapan akuntansi masjid yang bisa digunakan oleh Pengurus Masjid Paripurna nantinya sekaligus menjaadi bahan perbaikan kedepannya. Dengan menggunakan akun- akun yang sudah dipaparkan dalam teori.

\section{SIMPULAN}

Kesimpulan dari penelitian ini adalah penerapan akuntansi yang sesuai dengan aturan yang sudah diatur, masih sulit untuk diterapkan. Jelas terlihat dari informasi keuangan yang masih sederhana beserta wawancara yang diperoleh Peneliti dilapangan. Informasi keuangan dengan diumumkan setiap jum'at dan ditulis pada papan informasi masjid paripurna.

Bentuk pertanggung jawaban pengelolaan keuangan Masjid masih menggunakan pencatatan tunggal, atau lebih tepatnya akuntansi dana (menunjukkan sumber dana, dan penggunaanya disertai saldo setiap bulannya. Maka jika melihat pedoman PSAK 45 dan ISAK 35 serta akuntansi masjid dapat disimpulkan bahwa penerapan akuntansi keuangan di Mesjid 
Paripurna kota Pekanbaru belum sesuai dengan Prinsip Akuntansi Berterima Umum.

Meskipun nantinya penerapan akuntansi belum dapat diterapkan secara maksimal oleh badan pengelola, para pengurus badan pengelola dapat membuat laporan aktivitas sesuai dengan format atau standar akuntansi. Saran selanjutnya adalah Pemerintah kota Pekanbaru mesti menyediakan fasilitator dengan membentuk tim sebagai upaya mendukung perbaikan penerapan akuntansi masjid paripurna kedepannya. Lebih tepatnya adalah dengan memberikan pelatihan dan pendampingan kepada setiap perwakilan Badan Pengelola Masjid Paripurna. Saran lainnya adalah Badan Pengelola mengubah pola pikirnya menjadi pengurus yang berakuntabel dan profesional yakni agar meningkatkan perbaikan dalam penyusunan laporan keuangan Masjid Paripurna setiap tahunnya, yang juga berguna untuk transparansi dan akuntabilitas pengelolaan keuangan mesjid paripurna.

\section{DAFTAR PUSTAKA}

Astarani. (2016), Pencatatan Keuangan Masjid Yang Ada Di Kota Pontianak, http://Pekanbaru.SindoNews.com/2019/05/08/pekanbaru Membangun- Smart-CityMelalui- Masjid-Paripurna Diakses Tanggal 6 Oktober 2019Jam 17:34.

Azwirman, dkk. (2018),Analisis Penerapan Akuntasni Masjid Dengan Menggunakan MiscrosoftExcel For Accounting, Jurnal Ekonomi KIAT Vol.29, No 1, Juni, Hal.66-78.

Badu, Hambali (2014), Studi Ethnosecience: Dilema Transparansi dan Akuntabilitas Dalam Pelaporan Sumbangan Donatur dan Pengelolaan Keuangan Masjid (Studi Kasus Di Kabupaten Gororntalo), UniversitasGorontalo.

Bastian, Indra (2011), Akuntansi Sektor Publik:Suatu Pengantar, Erlangga, Yogyakarta.

Chenly Ribka S. Pontoh. (2013), Penerapan Laporan Keuangan, Jurnal EMBA 133 Vol.1 No.3 Juni, Hal. 129-139.

Fikal Putra (2018), Analisis Penerapan Akuntansi Dan Pelaporan Keuangan Pada Masjid Paripurna Di Pekanbaru (Studi Kasus Pada Masjid Paripurna Al-Falah Darul 
Muthaqin), Skripsi, Pekanbaru.

Halim, Abdul dan Muhammad Syam Kusufi (2016), Akuntansi Sektor Publik, Salemba Empat,

Jagaraksa.

Hendrawan, Rony (2011), Analisis Penerapan PSAK No.45 Tentang Pelaporan Keuangan Organisasi Nirlaba Pada Rumah Sakit Berstatus Badan Layanan Umum. Skripsi. Fakultas Ekonomi Universitas Diponegoro Semarang.

Ikatan Akuntan Indonesia. (2015). (PSAK) 45: Akuntansi Organisasi Nirlaba.Jakarta.

Ikatan Akuntan Indonesia (2018), (ISAK) 35: Penyajian Laporan Keuangan Entitas Berorientasi Nonlaba. Jakarta.

Kurniasari, Wiwin (2011), Transparansi Pengelolaan Masjid Dengan Laporan Keuangan Berdasarkan Pernyataan Standar Akuntansi Keuangan PSAK 45, Jurnal Muqtasid Volume 2 Nomor 1, Juli 2011, STAIN Salatiga.

Najmudin (2011), Manajemen Keuangan dan Akuntansi Syar'iyyah Modern, CV.Andi Offset, Yogyakarta.

PERDA No 2 Tahun 2016, Masjid Paripurna Kota Pekanbaru, Pemerintah Kota Pekanbaru.

Pulungan, Andrey Hasiholan, dkk (2013), Akuntansi Keuangan Dasar Berbasis PSAK Per Juni 2013, Buku 1, Mitra Wacana Media, Jakarta.

Ritonga, Rahmatika (2017), Anilisis Akuntabilitas Pengelolaan Keuangan Masjid Paripurna Di Kecamatan Payung sekaki Kota Pekanbaru, Skripsi UIN SUSKA Riau.

Sitompul, Syahman (2016), Implimentasi Surat Al-Baqarah Ayat 282 Dalam Pertanggungjawaban Mesjid Di Sumatera Timur Mhd. HUMAN FALAH: Volume 3. No. 2 Juli

- Desember 2016.Suherman, Eman (2012), Manajemen Masjid, Bandung: Penerbit Alfabeta.

Suwardjono (2014), Teori Akuntansi Perekayasaan Pelaporan Keuangan. Edisi Tīga. BPFE YOGYAKARTA. 